\title{
CONTRIBUTIONS MADE BY THE PORTUGUESE TO THE DEVELOPMENT OF BANTU LINGUISTICS BETWEEN 1500 AND 1917
}

\author{
Prof L.J. Louwrens*
}

In hierdie artikel gee Prof L.J. Louwrens, verbonde aan die Departement van Afrikatale aan die universiteit van Suid-Afrika, 'n oorsig van die bydraes wat die Portugese tot Bantoe-linguïstiek gemaak het. Die betrokke periode strek oor 'n tydperk van ongeveer vier eeue, en die artikel weergee hoogtepunte soos die eerste Portugese kontak met die Bantoe in 1471, die bydraes gemaak deur Jesuïete-sendelinge (veral in die 17de eeu) en die belangrike Portugese studies van Bantoe-tale in die 19de en 20ste eeue. In sy artikel benadruk Prof Louwrens deurgaans die reuse bydrae van die Portugese tot die vestiging van Bantoe-linguïstiek in Afrika.

\section{Introduction}

The contributions which the Portuguese have made to the development of Bantu linguistics extend over a period of approximately four centuries which commenced as early as 1550 (cf. Johnston (1919:2), lasting until as recently as the first quarter of the twentieth century. (Cf. Doke $(1945: 63))$.

According to Doke (1969:2), the Portuguese must have first made contact with the Bantu when they crossed the equator in 1471 . He observes, however, that although the first contact must have been made between Portuguese explorers and the Bantu on the west coast of Africa, the earliest records of Bantu words which were kept, were from the East African coast. Doke notes that this can be easiliy explained if it is remembered that the purpose of the initial Portuguese explorations was to establish a link with India. On the east coast they encountered severe opposition from Arabs, which forced them to establish strongholds at places such as Sofala, Kilwa and Mozambique. Trading posts were also established on the Zambesi at Tete and Sena, as well as in the more isolated regions of Masapa, Bukoto and Luanze.

As regards the first Bantu words recorded by Portuguese explorers, Doke (1969:3) remarks as follows:

"Prior to 1550 practically all the Bantu words recorded in Portuguese sources seem to be confined to place and personal names. There are references to "Monomotapa", "Zimbabwe", and the coastal towns of Sofala, Kilwa, Mozambique, etc., though these latter, Kilwa excepted, are hardly of Bantu origin."

\section{First records of Bantu}

In a letter by Diogo d'Alcaçova to the King Dom Manuel dated 20 November 1506, words are found in the Portuguese orthography referring to what is known today as Karanga and Zimbabwe. d'Alcaçova also mentions the title of the local king to be Menamotapam. The king's first name is rendered in six different ways: Quesarimgo, Quesarymgo, Quecarynugo, Quecarimugo, Quecarinuto and Quecarinugo. This king's father is referred to in two different ways, i.e. Mocomba or Mocombo. Similar words were documented by Affonso de Albuquerque in a letter to the King from Goa in India dated 25 October 1514, and by Duarte Barbosa in 1516 (Cf. Doke (1969: 3)).

Of these early records, Johnston (1919:2) remarks as follows:

"As early as 1505 but chiefly between the middle of the sixteenth century and 1760, Portuguese soldier-explorers and missionaries put into their writings numerous phrases from two East African Bantu tongues: Karaña ("Mocaranga") and Swahili. The amount of the former language which can be gleaned from these early records of Portuguese expeditions in Zambezia and on the Sofala coast is considerable..."

In 1560 the Jesuit missionary Father Gonçalo da Silveira landed at Sofala. Doke (1969:4) describes some of Silveira's experiences as follows:

"Silveira landed at Sofala in 1560 and after a short stay proceeded further north, up the Zambesi to Tete and further westward to the village of the "Monomotapa", where he was 
martyred on March 16th, 1561. In that short time he seriously studied both Tonga and $\mathrm{Ka}$ ranga. In a letter addressed to the "Fathers and Brothers of the college at Goa" he records the name of God as Umbe (cf. Hlangane dialect Illumbe). In an account "of the voyage of Father Dom Gonçalo to the Kingdom of Monomotapa and of his happy passing away", compiled on the instructions of the Father Provincial from various witnesses in 1561, several Bantu words occur, including the following: engangas "wizards who cast lots with four sticks" (cf Shona nanga 'diviner'), morefos "nobles of the kingdom" (cf. Shona murefu'a tall person'), moroo "wizard" (cf. Shona muroyi 'wizard', 'witch'); encoces "principal lord" which must be connected with the nguni terms inkosi 'chief'."

Other early records mentioned by Doke (1969:4-5) are those of Father André Fernandez in 1562, Father Monclaro in 1572 and Fr. Joano dos Santos in 1586.

\section{The seventeenth century}

Towards the third quarter of the seventeenth century the Portuguese had established themselves for a considerable period at posts such as Sena and Tete on the Zambesi river. This demanded the presence of priests for the ministration of the Christian gospel, who of necessity turned their attention to the Bantu languages. In this regard Doke (1935:102) mentions a publication by P.P. Schebesta which appeared in "Anthropos" under the German title: Eine Bantu-grammatik aus dem 17 Jahrhundert. This comprised a Portuguese manuscript entitled: Arte da lingua de Cafre which Schebesta discovered in the Bibliotheca Nacional d'Ajuda in Lisbon among a number of Jesuit manuscripts.

The document consisting of 42 pages was undated, but was among other documents of the year 1680. Doke (1935: 102-103) describes the contents of this manuscript as consisting of a few general notes on the pronouns equivalent to the Portuguese 1st., 2nd. and 3rd pers. singular and plural and their use with verbs. Then examples of various possessives with nouns are given, as well as some demonstratives and adjectives in concordial agreement with nouns. The great bulk of the work is taken up by tense after tense of the verb set out for each of the three persons in Portuguese and Sena following the classical paradigm of moods and tenses. The manuscript ends with some further notes on possessives, certain remarks on some preposit- ions and adverbs and a page of phrases in Portuguese and Sena.

The contributions made by the Portuguese during the seventeenth century are of particlar interest to Bantuists, since the first two books ever to be published on Bantu languages appeared during this period. The first Bantu publication of which we have record and which is mentioned by Doke (1935:87) is Cardoso's translation into Congo of Jorge's, Doutrina Christãa. It was printed in Lisbon in 1624, and Doke characterises Cardoso's work as "the first bit of continuous Bantu of which we know". He summarises its contents as follows:

"It is a catechism which is written throughout in Portuguese with an interlinear translation in Congo."

Cardoso was born in Lisbon in 1584 and entered the Jesuit order in 1598 at a very early age. After completing his studies at Evora, he was sent to the Congo to preach the Gospel. Here he became rector of the college of San Salvador and died on 20 October 1625. Doke (1935:88) quoting Barbot (1688) remarks as follows about this college:

"The Jesuits have a college where they daily teach and instruct the blacks in the Christian faith, in an easy and winning method. There are also schools where youths are brought up and taught Latin and Portuguese."

In this regard The New World Encyclopaedia (1963, Vol. 7, p. 328) states the following:

"Moreover Jesuit missionaries were sent to all
corners of the earth, and wherever they went
they carried with them learning and culture,
besides the spiritual message of their Church.
Thus they sent missionaries to China and
Japan, Brazil and the Portuguese settlements
in India, the Phillipine Islands, California and
Ethiopia, and not seldom suffered martyrdom.

Since the Jesuits played a major role in the earliest records of Bantu we know of, it is interesting to note the following about them: The Jesuit order was founded in 1534 by the Spaniard Ignatius Loyola. The training of a Jesuit lasted a considerable period. The New World Encyclopaedia (1963, Vol. 7, p. 327) reports as follows in this regard:

"In the training of a Jesuit, soon after his novitiate begins, 30 days are spent in meditation on the Spiritual Exercises, a manual which 
the founder himself composed; they are systematic presentations of the truths of religion, arranged so as to appeal both to the head and the heart, and so to strengthen the will of the student and purify his motives in submission to God and love of Christ. The novitiate lasts 2 years, and then simple vows of poverty, chastity, and obedience are taken. Those who are to be priests then do 2 or 3 years of philosophy, 5 years teaching in one of the society's schools, 4 years of theology, and, after an interval of several years, they have another year of probation (tertianship). After the third year of theology the scholastic is ordained priest. The normal period of training is thus about 13 years."

The second Bantu book we know of is by Pacconio and do Couto which was published in Lisbon in 1643 under the title Gentio de Angola. (Cf. Doke (1935:89-91). Again it is a book of Christian doctrine consisting of 90 pages written in Kimbundu, one of the languages spoken in Angola, with a Portuguese version on the opposite page. The original compiler of this source is believed to be Francesco Pacconio who was born at Capoue in 1589. He was admitted to the Jesuit order in 1607. After having completed his studies, he sailed from Lisbon in 1617 to what was then known as "The Kingdom of Angola" where he stayed for many years. He later returned to Lisbon where he died on 13 November 1641. At his death, Pacconio's Gentio de Angola was unfinished, but an Angolan colleague of his Antonio do Couto completed it. do Couto was of Portuguese origin, and was born at San Salvador on 31 October 1631. He served in the Congo as an evangelist, and died at Luanda on 16 July 1666. Since he was born amongst natives at San Salvador, it can be assumed that he had a thorough knowledge of the Congo language. He must also have had a knowledge of Kimbundu since he had shown his mastery of this language by completing Pacconio's Gentio de Angola. The contents of this work are described as follows by Doke (1935:91):

The Gentio de Angola contains the "Pater Noster", "Ave Maria", "Salve Regina", "Credo", "The Ten Commandments", etc. at the beginning, and then an exposition of Christian doctrine in the form of a dialogue, a "Discipulus" putting the questions, and the "Magister" answering thereto. There are a few introductory hints (in Portuguese) on pronunciation and grammar.
According to Werner (1919:5) a copy is still to be found in the library of the British Museum and she remarks as follows:

"In the library of the British Museum is a curious little book - with Southey's autograph, dated 'Keswick, 1810' on the title page printed in 1642 and containing a short exposition of elementary Christian doctrine in the form of a dialogue, in the language of Angola, with a Portuguese version on the opposite page, and a few introductory hints (in Portuguese) on pronunciation and grammar."

The reasons why two different publication dates are cited by Doke (i.e. 1643) and Werner (i.e. 1642) are not clear. The popularity which the Gentio enjoyed in those days is evident from the number of times it had been reprinted. In 1661 a second edition appeared which was a considerable improvement on the first. In this issue the author acknowledges the existence of semantic tone in Bantu - undoubtedly a commendable observation if it is kept in mind that it had been done more than three hundred years ago. A third edition was published in Lisbon in 1784 by order of Queen Maria I. In this edition the contents are also presented in three columns: Latin, Mbundu and Portuguese. In 1855 came yet a fourth edition entitled Explicaçoes de Doutrina Christãa em Portuguez e Angolese, paro uso das Missões do interior te Angola. This book was edited by Francisco de Sales Ferreira, a lieut-colonel in Angola, and was printed at the expense of Francisco Antonio Flores.

Little is known about other contributions by Portuguese missionaries during the seventeenth century. Doke (1935:103) summarises this situation as follows:

"Records of 17th century catechisms in Zambesi dialects are given, but hitherto none of these MSS have come to light. Two catechisms were reported in 1878 which were written by Dominican missionaries stationed at Tette. These were never published but it is assumed that they were probably in the Nyungwe dialect. Fr. Lucas de Santa Catharina in his Historia de San Domingos noted that the Zambesi missionaries of the 17th century had left behind them grammatical documents and catechisms in various Zambesi dialects."

The last publication we know of which appeared during the seventeenth century is an Angola grammar by Father Pedro Dias which was pub- 
lished in Lisbon in 1697. Dias was born at Gouvea in 1621 and entered the novitiate of the Jesuit order in 1641. (Cf. Doke (1935:103). He became rector of Olinda and died at Bahia in Brazil in 1700. This little book consists of 48 pages in addition to a short introductory section. According to Doke (1935:104), this is the first known grammatical treatise on the Kimbundu language.

Thus ends the seventeenth century, and from this point in time until the beginning of the nineteenth century there seems to be, according to Doke (1935:104), "an almost complete blank in Bantu publications". This resulted from the fact that the Jesuits became all the more unpopular with all the sovereigns of Europe, and were also expelled from Portugal by royal decree in 1759. (Cf. New World Encyclopaedia (1963: Vol. 7, p. 328).) About 1760 the Governor of Angola expelled the religious orders from San Salvador, and the place was unoccupied by them for over a hundred years.

We therefore turn our attention to the nineteenth century.

\section{The Nineteenth Century}

In 1979 Johnston summarised the role played by the Portuguese during the nineteenth century as follows:

"Nor in any record of Bantu discovery should the modern Portuguese be left out of account. Serpa Pinto, Capello and Ivens, in their works of the 'seventies and 'eighties of the last century had, as already related, given vocabularies of Angola and north-west Zambesia Bantu languages which have been of assistance to investigators; but in the 'nineties Henrique de Carvalho published that really important study of the Lunda language which is referred to in the Bibliography; and various Portuguese missionaries (especially Ernesto Lecomte and Affonso Maria-Lang) subsequently wrote excellent accounts of the northern members of the Hereró group in Southern Añgola (Umbundu and Nyaneka)."

Of these "modern" Portuguese, Doke (1935: 110-111) mentions Cannecattim, a missionary, who published in 1804 in Lisbon his Mbundu dictionary entitled Diccionario da Lingua Bunda ou Angolese explica na Portugueza e Latina. The work is arranged in three columns: Portuguese - Latin - Mbundu, and comprises 10000
Mbundu words. In 1805, also in Lisbon, Cannecattim published his Colleção de Observações Grammaticaes Sobre a Lingua Bunda ou Angolese, which consists of 238 pages.

Doke (1945:23-24) also mentions the remarkable Swiss missionary $\operatorname{Dr}$ Héli Chatelain who died in 1908. He went to Luanda in 1885 as a servant of "Bishop William Taylor's self-supporting missions in Africa". He was a remarkable man, since "he was acquainted with French and German, his two native languages, and also English, Italian, Spanish, Greek, Latin and Hebrew". However, Chatelain was handicapped by the self-supporting scheme, and he had to study Portuguese and keep himself by private tuition. He made an outstanding contribution with his Grammatica Elementar do Kimbundu which is "a thoroughly competent work in Portuguese, but with an English rendering of the examples". (Cf. Doke (1945:24).) This work, which appeared in 1889, was also translated in German as Gründzuge des Kimbundu oder der Angola-sprache. Chatelain also mentions three works by "an educated native of Angola" - J.D. Cordeiro, viz. a collection of proverbs and riddles with Portuguese translation published in 1891; a Kimbundu 'primer' published in 1892; and a Kimbundu - Portuguese dictionary Ensaio de Diccionaro Kimbundu-Portuguez published in 1893. The latter was considered by Chatelain to be the best vocabulary of Kimbundu published up until that time. (Cf. Doke (1945:24).)

\section{The Twentieth Century}

Doke (1945:63-95) mentions several publications by Portuguese authors which appeared between 1895 and 1924. In 1895 R. Paiva published a little handbook on Ronga spoken in the then Lourenco Marques entitled Noçoes de grammatica Landina a breve quia de conversaçao em portuguez, inglez e landim which consisted of 75 pages. In 1896 A.S. Pinheiro included Subsidios para a grammatica landina (Xijonga) de Lourenço Marques as a fragment of Portugal em Africa.

The last three publications referred to by Doke during this period are Paiva's Diccionario da lingua landina, português, ingles, landim which appeared in 1901; comprehensive vocabularies by E. Torre which appeared in 1906 under the little Diccionarios Shironga-Portuguez e Portuguez-Shironga and which consisted of 322 pages; as well as Father A.L. Farinha's Elemen- 
tos de Gramática Landina which appeared in 1917 consisting of 196 pages.

\section{Conclusion}

The contribution made by the Portuguese in establishing Bantu linguistics in Africa is rarely credited with the appraisal it deserves. Although "the first bit of continuous Bantu of which we know", (as Doke (1935:87) puts it), was documented by Cardoso in 1624, scholars and students of Bantu linguistics are generally unaware of this fact. This is more than disappointing. It is believed that this article will contribute to the conjuration of the ignorance which exists in this regard.
* Prof. L.J. Louwrens is attached to the Department of African Languages, University of South Africa.

\section{Bibliography}

Bozman, E.F. (1965) The New World Encyclopaedia. Vol. 7, Fourth Edition. (Edited by E.F. Bozman). New International Publications, Johannesburg. Doke, C.M. (1935) Early Bantu Literature: The Age of Brusciotto. Bantu Studies, Vol. 9. No. 2. The University of the Witwatersrand Press. Johannesburg.

- (1945) Bantu: Modern Grammatical, Phonetical and Lexicographical Studies Since 1860. Percy Lund, Humphries \& Co. London.

- (1969) The Earliest Records of Bantu. In Contributions to the History of Bantu Linguistics. The Witwatersrand University Press. Johannesburg. (By C.M. Doke \& D.T. Cole.)

Johnston, H.J. (1919) A Comprehensive Study of the Bantu and Semi-Bantu Languages. Vol. 1. The Clarendon Press. Oxford.

Werner, A. (1919) An Introductory Sketch of the Bantu Languages. Kegan Paul; Trench, Truber \& Co. London. 